\title{
BMJ Open Prevalence, determinants and impact of unawareness about the health consequences of tobacco use among 17929 school personnel in 29 African countries
}

\author{
Israel T Agaku, ${ }^{1}$ Filippos T Filippidis ${ }^{2}$
}

To cite: Agaku IT, Filippidis FT. Prevalence, determinants and impact of unawareness about the health consequences of tobacco use among 17929 school personnel in 29 African countries. BMJ Open 2014:4:e005837.

doi:10.1136/bmjopen-2014005837

- Prepublication history for this paper is available online. To view these files please visit the journal online (http://dx.doi.org/10.1136/ bmjopen-2014-005837).

Received 2 June 2014 Revised 8 July 2014 Accepted 1 August 2014

CrossMark

For numbered affiliations see end of article.

Correspondence to Dr Israel Agaku; iagaku@post.harvard.edu

\section{ABSTRACT}

Objectives: To assess prevalence, determinants and impact of unawareness about the health consequences of tobacco use among school personnel in Africa.

Design: Cross-sectional surveys.

Setting: Twenty-nine African countries.

Participants: Representative samples of school personnel from 29 African countries ( $n=17$ 929), using data from the 2006-2011 Global School Personnel Surveys.

Outcome: We assessed if school personnel were aware of the following five facts about tobacco use: (1) tobacco use is addictive; (2) secondhand smoke exposure is harmful; (3) smoking causes lung cancer; (4) smoking causes heart disease and (5) smoking does not cause malaria. Using multivariate logistic regression, we measured the impact of unawareness of the health consequences of tobacco use on behaviour and attitudes towards tobacco control.

Results: A median of $62.6 \%$ of school personnel were unaware of at least one health consequence of tobacco use. School personnel in countries with mandatory cigarette health warning labels had lower odds of being unaware of any health consequence of tobacco use than countries where health warning labels were not mandatory (adjusted $\mathrm{OR}[\mathrm{aOR}]=0.51$; $95 \% \mathrm{Cl} 0.37$ to 0.71 ). A significant dose-response relationship was seen between being ignorant of 1 ; 2 ; or $\geq 3$ tobacco use health consequences respectively (compared with not being ignorant of any), and the odds of the following outcomes: non-support of bans on tobacco industry sponsorship of school or extracurricular activities (aOR=1.47; 1.91; and 2.98); non-support of bans on all tobacco advertisements $(\mathrm{aOR}=1.24 ; 1.78$; and 2.68) and non-support of policies prohibiting tobacco use by school personnel on campus (aOR=1.79; 4.45; and 4.56).

Conclusions: Unawareness of the health consequences of tobacco use was associated with poor support for tobacco control policies. Intensified efforts are needed in African countries to warn about the dangers of tobacco use.

\section{Strengths and limitations of this study}

- Large sample size with standardised methodology across 29 African countries.

- Assessment of several domains of knowledge about the health consequences of tobacco use.

- Self-reported nature of the data may be subject to misreporting.

- The cross-sectional design precludes causal inferences and only associations can be drawn.

- Since nationally representative data were not available for all countries within each region in Africa, these findings may not be representative of the respective regions or of Africa as a whole.

\section{INTRODUCTION}

With the continuing decline in cigarette smoking in high-income countries, ${ }^{1}$ Africa has become a prime target of the tobacco industry because of its favourable demographic and legislative climate. Africa is one of the fastest growing continents. Its population grew exponentially from 228 million in 1950 to over 1.03 billion in 2010, and is projected to more than double by 2050 to over 2.39 billion. $^{2}$ Additionally, the population pyramid of sub-Saharan Africa, unlike that of developed nations, is characterised by a very broad base, indicating a predominance of children, adolescents and young adults, ${ }^{3}-\mathrm{a}$ very susceptible population with regards tobacco initiation. This is further aggravated by the relatively weak stance on implementation and enforcement of tobacco control policies in this region. Although most African countries have ratified the WHO's Framework Convention on Tobacco Control (FCTC) ${ }^{1}$ progress in the implementation of WHO FCTC articles has been weak to modest, and existing legislation often does not meet the standards set by the WHO. ${ }^{4}$ 
Discussions of disease and health in Africa and other low- and middle-income countries (LMICs) often focus on infectious diseases. However, according to the WHO, chronic diseases exert a huge toll, with LMICs contributing $80 \%$ of global non-communicable disease deaths, including those resulting from tobacco use and secondhand smoke exposure. ${ }^{5}$ Hence, preventing tobacco use, especially among adolescents and young adults, is an urgent priority to avert a tobacco epidemic and reduce the burden of tobacco-attributable diseases and death in LMICs. As tobacco control legislation matures in several African countries, the involvement of key stakeholders with vested interests in tobacco prevention is paramount, in line with article 12 of the WHO FCTC, which calls for engagement of civic societies in tobacco control efforts. ${ }^{6}$

School personnel are respected members of the society and could potentially play a significant role in tobacco use prevention and health promotion efforts among youths. Given their responsibility to instruct and educate students, school personnel can shape tobaccorelated knowledge, attitudes and behaviours of adolescents and young adults, and help to define what is normative in society. In addition, since school teachers may be some of the more educated members of some communities (particularly in rural areas where levels of educational attainment may be relatively low, and sources of health information limited), the extent of their misconceptions about tobacco use may indicate even greater gaps in knowledge among the larger community. A deeper understanding of such knowledge gaps may help to guide the development of tailored mass media campaigns warning about the dangers of tobacco use as part of a comprehensive tobacco control programme, in line with the WHO MPOWER package. ${ }^{7}$

Thus, the level of school personnel's knowledge about tobacco use and its aftermaths, and factors which may influence school personnel's support for tobacco control policies warrant closer examination. To this end, this study assessed the knowledge of school personnel from 29 African countries about the health consequences of tobacco use, and the impact on their support for tobacco control programmes and policies. Data were obtained from the 2006-2011 Global School Personnel Surveys (GSPS).

\section{METHODS}

\section{Data source/sample}

This study analysed data for a total of $\mathrm{n}=17929$ school personnel from 29 countries in Africa that participated in the 2006-2011 GSPS. ${ }^{8}$ The GSPS is a survey of school personnel sampled from schools that participated in the Global Youth Tobacco Survey-a survey of adolescent students aged 13-15 years. The sampling frame of the Global Youth Tobacco Survey in each country or site comprised all schools, both public and private. ${ }^{8}$ The sampling frame of the GSPS included all the schools selected for the Global Youth Tobacco Survey.
The sample sizes and survey years for the 29 countries included in our study are shown in table 1 . These were grouped into five subregions, according to the United Nations geo-scheme as follows': (1) Southern Africa: Namibia, Swaziland, South Africa and Lesotho. (2) Western Africa: Burkina Faso, Ghana, Mauritania, Niger, Senegal, Togo, Guinea Bissau and Sierra Leone. (3) Central Africa: Cameroon (Central District); Democratic Republic of Congo (Kinshasa), Republic of Congo and Central African Republic (Bangui). (4) Eastern Africa: Djibouti, Somalia (Somaliland), Malawi, Uganda, Eritrea, Seychelles, Mauritius, Rwanda and Zimbabwe (Harare). (5) Northern Africa: Morocco, Tunisia, Libya, and Sudan.

\section{Measures}

\section{Domains of knowledge}

We assessed awareness of the health consequences of tobacco use under five domains of knowledge ${ }^{10}{ }^{11}$ namely, (1) causal relationship between tobacco use and malaria, assessed by asking "Does tobacco use cause malaria?"; (2) causal relationship between tobacco use and lung cancer, assessed by asking "Does tobacco use cause lung cancer?"; (3) causal relationship between tobacco use and heart disease, assessed by asking "Does tobacco use cause heart disease?"; (4) addictiveness of tobacco use, assessed by asking "Is tobacco use addictive?"; (5) harmfulness of secondhand smoke exposure, assessed by asking "Do you think smoke from other people's cigarettes is harmful to you?"

Each of these five questions had three categorical response options-'Yes', 'No' or 'Don't know'. For the relationship between tobacco use and malaria (ie, "Does tobacco use cause malaria?"), a response of either 'Yes' or 'Don't know' was classified to indicate unawareness about the relationship between tobacco use and malaria. For the other knowledge domains assessed in (2)-(5) above, a response of either 'No' or 'Don't know' to the respective questions was classified to indicate unawareness about the health effect of tobacco use. We further summarised these data by creating a composite variable denoting the number of distinct health consequences of tobacco use of which each respondent was unaware, ranging from 0 (ignorance in none of the five knowledge domains) to 5 (ignorance in all five domains).

\section{Current tobacco use and exposure to pro-tobacco advertisements}

Current cigarette smokers were defined as adults who had smoked 100 cigarettes or more during their lifetime, and who reported smoking cigarettes 'daily' or 'occasionally' at the time of the survey. Current use of bidis, cigars, pipes, chewing tobacco or snuff was defined as 'daily' or 'occasional' use of these products. Current use of any tobacco product was defined as current use of cigarettes, bidis, cigars, pipes, or smokeless tobacco products. 
Table 1 Characteristics of school personnel from 29 African countries, 2006-2011 ( $n=17$ 929)

\begin{tabular}{|c|c|c|c|c|}
\hline Characteristics & $\begin{array}{l}\text { Survey } \\
\text { year }\end{array}$ & $\begin{array}{l}\text { Class teachers } \\
(\%)\end{array}$ & $\begin{array}{l}\text { Female subjects } \\
(\%)\end{array}$ & $\begin{array}{l}\text { Current any tobacco use } \% \\
(95 \% \mathrm{Cl})\end{array}$ \\
\hline \multicolumn{5}{|l|}{ Southern Africa } \\
\hline Namibia $(\mathrm{n}=746)$ & 2008 & 89.5 & 55.6 & $10.3(6.5$ to 14.1$)$ \\
\hline Swaziland $(n=473)$ & 2009 & 95.2 & 58.4 & 7.8 (5.7 to 9.9$)$ \\
\hline South Africa $(n=1485)$ & 2011 & 94.2 & 62.7 & 7.8 (4.6 to 11$)$ \\
\hline Lesotho $(n=103)$ & 2008 & 90.3 & 67.0 & $5.8(\mathrm{~N} / \mathrm{A})$ \\
\hline \multicolumn{5}{|l|}{ Western Africa } \\
\hline Burkina Faso $(n=862)$ & 2009 & 90.3 & 29.9 & 8.8 (4.9 to 12.7 ) \\
\hline Ghana $(n=391)$ & 2009 & 85.1 & 32.5 & $5.2(1.9$ to 8.5$)$ \\
\hline Mauritania $(n=505)$ & 2009 & 83.0 & 54.3 & $11.2(7.2$ to 15.3$)$ \\
\hline Niger $(n=624)$ & 2009 & 92.7 & 77.3 & $11.3(7.7$ to 14.8$)$ \\
\hline Senegal $(n=619)$ & 2007 & 93.9 & 19.6 & 15.9 (9.5 to 22.2) \\
\hline Togo $(n=488)$ & 2007 & 92.3 & 8.2 & 6.3 (2.5 to 10.2$)$ \\
\hline Guinea Bissau $(n=555)$ & 2008 & 96.0 & 31.9 & $6.8(\mathrm{~N} / \mathrm{A})$ \\
\hline Sierra Leone $(n=914)$ & 2008 & 93.5 & 75.7 & 9.8 (7.2 to 12.5$)$ \\
\hline \multicolumn{5}{|l|}{ Central Africa } \\
\hline Cameroon (Central District) $(n=1712)$ & 2008 & 81.3 & 41.7 & 19.6 (16.6 to 22.7$)$ \\
\hline $\begin{array}{l}\text { Democratic Republic of Congo } \\
\text { (Kinshasa) }(n=299)\end{array}$ & 2008 & 85.5 & 82.2 & 27.0 (20.7 to 33.4$)$ \\
\hline Republic of Congo $(n=453)$ & 2009 & 82.3 & 24.1 & 22.1 (14.8 to 29.4$)$ \\
\hline $\begin{array}{l}\text { Central African Republic (Bangui) } \\
(n=497)\end{array}$ & 2008 & 87.2 & 21.6 & 30.2 (19.1 to 41.2$)$ \\
\hline \multicolumn{5}{|l|}{ Eastern Africa } \\
\hline Djibouti $(n=498)$ & 2009 & 77.5 & 75.4 & 41.6 (36.1 to 47.2$)$ \\
\hline Somalia (Somaliland) $(n=214)$ & 2007 & 78.8 & 86.7 & 38.1 (25.3 to 51.0$)$ \\
\hline Malawi $(n=276)$ & 2009 & 89.2 & 40.1 & $4.4(1.1$ to 7.6$)$ \\
\hline Uganda $(n=682)$ & 2011 & 88.8 & 48.5 & 4.9 (2.0 to 7.8$)$ \\
\hline Eritrea $(n=1446)$ & 2006 & 91.7 & 36.4 & 9.6 (7.9 to 11.4$)$ \\
\hline Seychelles $(n=516)$ & 2007 & 75.8 & 54.4 & $10.7(8.1$ to 13.4$)$ \\
\hline Mauritius $(n=863)$ & 2008 & 97.2 & 55.6 & $11.1(7.7$ to 14.5$)$ \\
\hline Rwanda $(n=200)$ & 2008 & 91.8 & 21.1 & 2.3 (0.2 to 4.3$)$ \\
\hline Zimbabwe (Harare) $(n=233)$ & 2008 & 95.3 & 66.1 & $5.2(\mathrm{~N} / \mathrm{A})$ \\
\hline \multicolumn{5}{|l|}{ Northern Africa } \\
\hline Morocco $(n=699)$ & 2010 & 77.1 & 66.5 & 21.5 (12.8 to 30.1$)$ \\
\hline Tunisia $(n=66)$ & 2010 & 98.5 & 43.1 & $22.7(\mathrm{~N} / \mathrm{A})$ \\
\hline Libya $(n=1241)$ & 2010 & 76.8 & 36.7 & 20.3 (18.1 to 22.5$)$ \\
\hline Sudan $(n=269)$ & 2009 & 86.9 & 57.3 & 8.5 (6.3 to 10.6$)$ \\
\hline
\end{tabular}

As an indicator for exposure to point-of-sale protobacco advertisements in school, we assessed the presence of tobacco retail outlets on school grounds with the question: "Can cigarettes or tobacco products be purchased inside your school buildings?". Categorical response options were 'Yes' or 'No'.

\section{Attitude and behaviour towards tobacco use prevention among youths}

We assessed school personnel's attitude towards tobacco use prevention among the youth by asking the following three questions: (1) "How concerned are you about tobacco use among youth in your community?". Categorical response options were "Not at all concerned', 'Somewhat concerned' or 'Very concerned'. (2) "Have you ever advised a student to stop using tobacco?". Categorical response options were 'Yes' or
'No'. (3) "Do you think teacher tobacco use influences youth tobacco use?". Categorical response options were 'Yes' or 'No'.

\section{Perception of tobacco control policies}

We assessed school personnel's attitude towards several tobacco control policies by asking different viewpoint questions, each of which had categorical response options of 'Yes' or 'No'. The questions were: (1) "Do you think schools should have a policy or rule specifically prohibiting tobacco use among students on school premises/property?". (2) "Do you think schools should have a policy or rule specifically prohibiting tobacco use among school personnel on school premises/property?". (3) "Do you think cigarette smoking should be banned in public places?". (4) "Do you think the tobacco industry should be allowed to sponsor school or 
extracurricular activities, such as sporting events?”. (5) "Do you think tobacco product advertising should be completely banned?". (6) "Do you think the price of tobacco products should be increased?".

With the exception of question (4), a response of 'No' was indicative of non-support for the assessed tobacco control policy.

\section{Sociodemographic and school-related characteristics}

Sociodemographic characteristics assessed included age (<30; 30-39; 40-49 or $\geq 50$ years), sex (male or female), type of school personnel (teacher or administrative staff such as school principal or school nurse), extent involved in teaching about health (not at all involved; not a primary duty but teach sometimes; or primary duty and teach all the time), access to educational materials in school on tobacco use prevention (yes or no), survey year (2006 through 2011) and presence of mandatory cigarette health warnings in country (yes or no). In total, nine of 29 countries assessed did not have mandatory cigarette health warning labels. These were Uganda, Togo, Sierra Leone, Rwanda, Mauritania, Malawi, Congo, Central African Republic and Somalia. ${ }^{1}$

\section{Data analyses}

We calculated the proportions of school personnel that were unaware of the health consequences of tobacco use in each of the five domains assessed, as well as in any domain. Determinants of unawareness of the health consequences of tobacco use were assessed in a binary logistic regression model that assessed for extent involved in teaching about health, region, survey year, age, type of school personnel, sex, smoking status, presence of mandatory health warning labels on tobacco products, access to educational materials in school on tobacco use prevention and presence of tobacco retail outlets on school grounds $(\mathrm{p}<0.05)$.

Finally, we fitted multiple logistic regression models to assess the impact of unawareness of the health consequences of tobacco use on support for various tobacco control policies, as well as on attitudes and behaviour towards tobacco use, controlling for the aforementioned factors. All analyses were weighted and performed with Stata V.12.

\section{RESULTS \\ Prevalence of unawareness of the health consequences of tobacco use}

Among the 29 sites included in the study, a median of $62.6 \%$ of all school personnel were unaware of at least one health consequence of tobacco use. Among the five domains of knowledge assessed, unawareness that tobacco use does not cause malaria was the highest (median $=36.4 \%$, range $10.1 \%$ in Senegal to $66.2 \%$ in Bangui, Central African Republic) (table 2). This was followed, in descending order, by unawareness that tobacco use is addictive (median $=20.1 \%$, range $5.6 \%$ in
South Africa to $65.7 \%$ in Senegal), tobacco use causes heart disease (median $=12.8 \%$, range $0.0 \%$ in Tunisia to $36.6 \%$ in Malawi), tobacco use causes lung cancer (median $=5.1 \%$, range $0.0 \%$ in Tunisia to $80.4 \%$ in Somaliland, Somalia) and secondhand smoke exposure is harmful (median=4.3\%, range $0.0 \%$ in Lesotho and Tunisia to $25.2 \%$ in Somaliland, Somalia).

\section{Determinants of unawareness of the health consequences of tobacco use}

The odds of being unaware that tobacco use does not cause malaria were higher among respondents in West Africa than in Southern Africa (adjusted OR [aOR] $=1.76 ; 95 \%$ CI 1.34 to 2.32). Similarly, in comparison with respondents from Southern Africa, the odds of being unaware that tobacco use is addictive were higher among respondents in Central $(\mathrm{aOR}=1.64 ; 95 \%$ CI 1.08 to 2.49) and Eastern Africa (aOR=1.63; $95 \%$ CI 1.19 to 2.23) (Table 3).

School personnel whose primary duty was teaching about health had significantly lower odds of being unaware that tobacco use causes lung cancer (aOR= 0.38 ; $95 \%$ CI 0.17 to 0.83 ) or heart disease $(\mathrm{aOR}=0.37$; $95 \%$ CI 0.23 to 0.58 ) than those who did not teach about health at all. School personnel for whom teaching about health was not their primary duty, but who did so sometimes, also had lower odds of being unaware that tobacco use causes heart disease than those who did not teach about health at all $(\mathrm{aOR}=0.54 ; 95 \%$ CI 0.37 to $0.77)$.

Respondents in countries with mandatory health warnings on cigarettes had lower odds of being unaware that tobacco use is addictive $(\mathrm{aOR}=0.37 ; 95 \%$ CI 0.30 to $0.48)$; that tobacco causes either lung cancer $(\mathrm{aOR}=0.54 ; 95 \%$ CI 0.31 to 0.92$)$ or heart disease $(\mathrm{aOR}=0.30 ; 95 \%$ CI 0.20 to 0.46$)$; or that secondhand smoke exposure is harmful (aOR=0.50; 95\% CI 0.26 to 0.98). School personnel who had tobacco retail outlets on their school premises had higher odds of being unaware that tobacco use causes lung cancer $(\mathrm{aOR}=2.09$; 95\% CI 1.07 to 4.08$)$.

Other determinants of unawareness of the health consequences of tobacco use are shown in table 3.

\section{Impact of unawareness of the health consequences of tobacco use on tobacco-related behaviours, perceptions and attitudes}

Among all school personnel, the prevalence of current tobacco use ranged from $2.3 \%$ in Rwanda to $41.6 \%$ in Djibouti. A significant dose-response relationship was seen between being unaware of one, two or three or more health consequences of tobacco use, respectively (compared with not being ignorant of any), and the odds of the following outcomes: being 'not at all concerned' about tobacco use among youths in the community $(\mathrm{aOR}=1.86 ; 2.54$ and 6.00), perception that teachers' tobacco use does not influence youth tobacco use $(\mathrm{aOR}=1.01 ; 3.88$ and 4.79$)$, non-support of policies 
Table 2 Prevalence of unawareness of various health consequences of tobacco use among school personnel from 29 African countries, 2006-2011 ( $\mathrm{n}=17$ 929)

\begin{tabular}{|c|c|c|c|c|c|c|}
\hline Region/country & $\begin{array}{l}\text { Unawareness that } \\
\text { tobacco use does } \\
\text { not cause malaria } \\
\%(95 \% \mathrm{Cl})\end{array}$ & $\begin{array}{l}\text { Unawareness that } \\
\text { tobacco use is } \\
\text { addictive } \\
\%(95 \% \mathrm{Cl})\end{array}$ & $\begin{array}{l}\text { Unawareness that } \\
\text { tobacco use } \\
\text { causes lung cancer } \\
\%(95 \% \mathrm{Cl})\end{array}$ & $\begin{array}{l}\text { Unawareness that } \\
\text { tobacco use } \\
\text { causes heart } \\
\text { disease } \\
\%(95 \% \mathrm{Cl})\end{array}$ & $\begin{array}{l}\text { Unawareness that } \\
\text { secondhand smoke } \\
\text { exposure is harmful } \\
\%(95 \% \mathrm{Cl})\end{array}$ & $\begin{array}{l}\text { Unawareness in } \\
\text { one or more } \\
\text { domains } \\
\%(95 \% \mathrm{Cl})\end{array}$ \\
\hline \multicolumn{7}{|l|}{ Southern Africa } \\
\hline Namibia (n=746) & 30.6 (26.7 to 34.4$)$ & 19.7 (16.3 to 23.2$)$ & 3.2 (2.0 to 4.4$)$ & $21.0(16.1$ to 26.0$)$ & 11.1 (7.7 to 14.4$)$ & 54.1 (48.5 to 59.7 ) \\
\hline Swaziland $(n=473)$ & 36.4 (30.6 to 42.3 ) & 7.8 (5.3 to 10.3$)$ & 4.1 (2.7 to 5.4$)$ & 27.6 (22.3 to 32.8$)$ & $2.9(1.3$ to 4.5$)$ & 54.6 (49.7 to 59.4$)$ \\
\hline South Africa $(n=1485)$ & 31.0 (21.5 to 40.4$)$ & $5.6(1.9$ to 9.4$)$ & $2.8(0.4$ to 5.1$)$ & 12.7 (8.8 to 16.6$)$ & $8.0(4.3$ to 11.6$)$ & 47.4 (39.3 to 55.6$)$ \\
\hline Lesotho $(n=103)$ & $50.5(\mathrm{~N} / \mathrm{A})$ & $21.8(\mathrm{~N} / \mathrm{A})$ & $2.9(\mathrm{~N} / \mathrm{A})$ & $14.9(\mathrm{~N} / \mathrm{A})$ & 0.0 & $65.0(\mathrm{~N} / \mathrm{A})$ \\
\hline \multicolumn{7}{|l|}{ West Africa } \\
\hline Burkina Faso $(n=862)$ & 44.8 (33.6 to 56.1 ) & 9.2 (4.9 to 13.5$)$ & 5.7 (2.8 to 8.6$)$ & $9.9(5.2$ to 14.5$)$ & 3.1 (0.9 to 5.2 ) & 54.8 (43.9 to 65.6 ) \\
\hline Ghana $(n=391)$ & 50.5 (43.1 to 57.9 ) & $13.8(8.7$ to 19.0$)$ & $3.9(0.7$ to 7.1$)$ & 4.7 (1.6 to 7.8$)$ & $2.2(0.2$ to 4.3$)$ & 58.5 (51.9 to 65.2$)$ \\
\hline Mauritania $(n=505)$ & 63.5 (55.3 to 71.6 ) & 17.5 (10.7 to 24.2$)$ & 4.1 (1.7 to 6.5$)$ & 23.4 (19.5 to 27.3$)$ & $2.0(0.8$ to 3.3$)$ & 72.8 (65.7 to 79.8$)$ \\
\hline Niger $(n=624)$ & 53.7 (47.5 to 59.9$)$ & 25.1 (19.9 to 30.3$)$ & 10.7 (8.8 to 12.5$)$ & 26.4 (22.5 to 30.3$)$ & $1.7(0.0$ to 3.4$)$ & 70.7 (66.7 to 74.6$)$ \\
\hline Senegal $(n=619)$ & 10.1 (5.3 to 15.0$)$ & 65.7 (55.2 to 76.3$)$ & 2.2 (0.5 to 3.9$)$ & $12.2(8.0$ to 16.3$)$ & $5.0(2.9$ to 7.1$)$ & 72.6 (63.9 to 81.4$)$ \\
\hline Togo $(n=488)$ & 61.4 (54.6 to 68.2$)$ & 26.7 (21.8 to 31.7$)$ & $5.1(3.2$ to 7.0$)$ & $10.6(7.8$ to 13.5$)$ & $1.5(0.1$ to 2.8$)$ & 71.4 (65.9 to 76.8$)$ \\
\hline Guinea Bissau $(n=555)$ & $44.7(\mathrm{~N} / \mathrm{A})$ & $42.8(\mathrm{~N} / \mathrm{A})$ & $6.7(\mathrm{~N} / \mathrm{A})$ & $21.8(\mathrm{~N} / \mathrm{A})$ & $5.8(\mathrm{~N} / \mathrm{A})$ & $76.8(\mathrm{~N} / \mathrm{A})$ \\
\hline Sierra Leone $(n=914)$ & 49.3 (44.5 to 54.0$)$ & 17.7 (12.2 to 23.1$)$ & 11.1 (8.7 to 13.6$)$ & $20.2(17.3$ to 23.1$)$ & $5.8(4.3$ to 7.3$)$ & 62.6 (58.1 to 67.1$)$ \\
\hline \multicolumn{7}{|l|}{ Central Africa } \\
\hline $\begin{array}{l}\text { Cameroon (Central District) } \\
(n=1712)\end{array}$ & 53.3 (47.8 to 58.7$)$ & 22.1 (16.7 to 27.4 ) & $8.8(6.9$ to 10.7$)$ & 20.0 (16.7 to 23.3$)$ & $2.5(1.4$ to 3.6$)$ & 68.4 (64.1 to 72.6$)$ \\
\hline $\begin{array}{l}\text { Democratic Republic of } \\
\text { Congo (Kinshasa) }(n=299)\end{array}$ & 41.9 (31.7 to 52.1$)$ & $22.2(12.5$ to 31.8$)$ & $11.0(6.8$ to 15.2$)$ & 18.1 (9.1 to 27.0$)$ & 6.7 (3.8 to 9.6$)$ & 61.2 (53.7 to 68.7$)$ \\
\hline Republic of Congo $(n=453)$ & 30.6 (22.8 to 38.4$)$ & $37.1(24.2$ to 50.0$)$ & 8.7 (7.2 to 10.2$)$ & 20.9 (17.7 to 24.2$)$ & 4.3 (1.3 to 7.3$)$ & 67.3 (62.0 to 72.6$)$ \\
\hline $\begin{array}{l}\text { Central African Republic } \\
\text { (Bangui) }(n=497)\end{array}$ & 66.2 (59.2 to 73.2 ) & 24.3 (18.3 to 30.4 ) & $5.4(3.7$ to 7.1$)$ & 14.4 (8.8 to 20.0$)$ & $1.6(0.8$ to 2.5$)$ & 74.3 (67.1 to 81.5 ) \\
\hline \multicolumn{7}{|l|}{ Eastern Africa } \\
\hline Djibouti $(n=498)$ & 50.2 (47.5 to 52.9 ) & 17.8 (15.4 to 20.3 ) & 11.1 (9.4 to 12.7 ) & 9.3 (7.3 to 11.3$)$ & 7.8 (6.2 to 9.4$)$ & 63.5 (60.8 to 66.2$)$ \\
\hline $\begin{array}{l}\text { Somalia (Somaliland) } \\
(n=214)\end{array}$ & 51.3 (33.6 to 69.0$)$ & 65.2 (48.8 to 81.7 ) & 80.4 (72.5 to 88.3$)$ & 23.6 (12.3 to 34.9$)$ & 25.2 (13.9 to 36.4$)$ & 99.2 (98.1 to 100.0$)$ \\
\hline Malawi $(n=276)$ & 23.1 (10.9 to 35.3$)$ & 41.6 (32.7 to 50.5$)$ & 8.0 (2.9 to 13.0$)$ & 36.6 (22.0 to 51.2$)$ & 12.3 (3.4 to 21.2 ) & 73.7 (59.0 to 88.4$)$ \\
\hline Uganda $(n=682)$ & $18.0(8.2$ to 27.7$)$ & 20.1 (13.8 to 26.3 ) & $3.2(0.4$ to 6.0$)$ & $12.6(8.1$ to 17.1$)$ & $4.3(1.5$ to 7.1$)$ & $43.2(27.8$ to 58.7$)$ \\
\hline Eritrea $(n=1446)$ & 37.6 (30.4 to 44.7$)$ & 43.3 (36.7 to 49.8 ) & 7.2 (3.6 to 10.7$)$ & 11.1 (7.9 to 14.2$)$ & $10.8(7.5$ to 14.1$)$ & $68.3(61.7$ to 74.9$)$ \\
\hline Seychelles $(n=516)$ & 35.1 (30.7 to 39.5$)$ & $8.5(6.8$ to 10.1$)$ & $3.2(2.4$ to 3.9$)$ & $9.2(6.9$ to 11.5$)$ & $6.0(4.5$ to 7.6$)$ & 45.6 (41.9 to 49.3$)$ \\
\hline Mauritius $(n=863)$ & 36.4 (31.7 to 41.1$)$ & $13.5(9.2$ to 17.7$)$ & 4.4 (1.5 to 7.3$)$ & 12.8 (9.5 to 16.2$)$ & 5.5 (2.3 to 8.6$)$ & 49.4 (46.2 to 52.6$)$ \\
\hline Rwanda $(n=200)$ & 31.6 (23.4 to 39.9$)$ & $33.2(25.5$ to 40.9$)$ & 5.9 (3.2 to 8.7$)$ & 10.7 (5.7 to 15.8$)$ & $1.1(0.0$ to 2.6$)$ & 56.1 (47.8 to 64.4$)$ \\
\hline Zimbabwe (Harare) $(n=233)$ & $32.9(\mathrm{~N} / \mathrm{A})$ & $46.1(N / A)$ & $-^{*}-x^{-}$ & $-^{*}-n^{-}$ & $6.1(\mathrm{~N} / \mathrm{A})$ & $66.1(\mathrm{~N} / \mathrm{A})$ \\
\hline
\end{tabular}




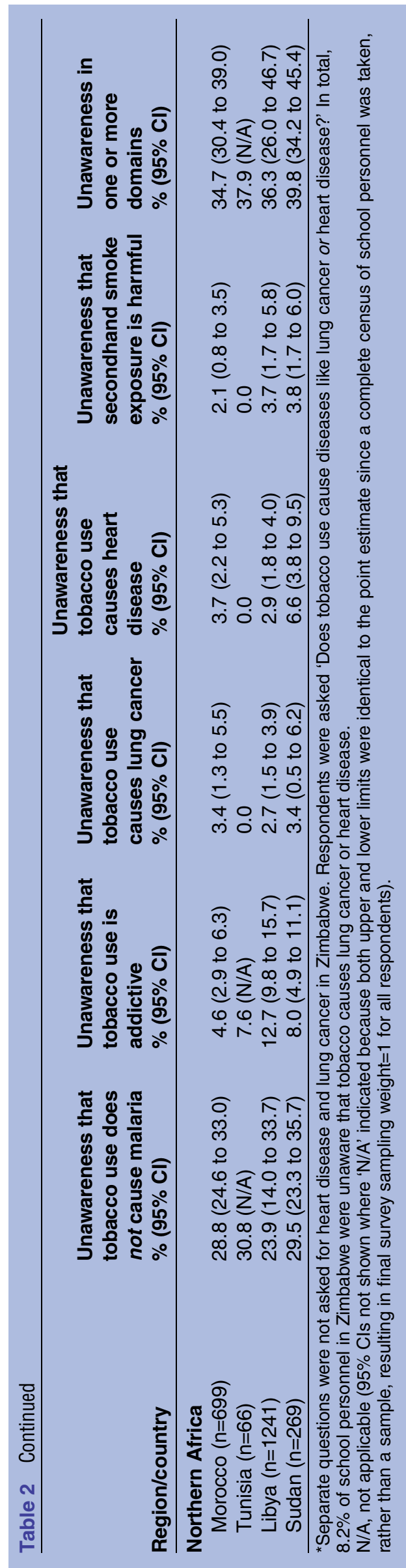

prohibiting tobacco use by school personnel on campus $(\mathrm{aOR}=1.79 ; 4.45$ and 4.56), non-support of bans on tobacco industry sponsorship of school or extracurricular activities $(\mathrm{aOR}=1.47 ; 1.91$ and 2.98) and non-support of bans on all tobacco advertisements $(\mathrm{aOR}=1.24 ; 1.78$ and 2.68) (table 4). Similarly, unawareness of three or more health consequences of tobacco use (compared with not being ignorant of any) was associated with increased odds of current cigarette smoking $(\mathrm{aOR}=2.14$; 95\% CI 1.10 to 4.17 ), non-support of price increases on tobacco products $(\mathrm{aOR}=1.67 ; 95 \%$ CI 1.01 to 2.67$)$ and having never advised a student to stop using tobacco $(\mathrm{aOR}=2.74 ; 95 \%$ CI 1.48 to 5.08$)$.

\section{DISCUSSION}

Our analysis showed that about two-thirds of all school personnel were unaware of at least one of the five health consequences of smoking assessed. Most respondents ( $>90 \%$ in 25 of 29 sites) were aware that secondhand smoke is harmful. This widespread knowledge about the harmfulness of secondhand smoke among school personnel may be particularly beneficial for public health if it prevents or reduces tobacco use, and discourages school personnel from smoking in the presence of children. This is pertinent since secondhand smoke exposure is especially dangerous for children and adolescents, and no safe levels of exposure exist. ${ }^{12}$ We also found relatively high levels of awareness that tobacco use causes lung cancer and heart disease. Previous research comparing knowledge of health risks of tobacco smoking among smokers in four high-income countries (USA, Canada, UK and Australia) showed similarly high awareness (>85\% of all respondents). ${ }^{10}$

Our study also showed that school personnel who were ignorant of several health consequences of tobacco use were less likely to be concerned about preventing tobacco use among youth, or to believe that teachers' smoking habits catalyse tobacco use among students. Consequently, school personnel who were ignorant of several health consequences were also less likely to have ever advised students to quit smoking. This is of great importance in several LMICs, where tobacco control is in its relative infancy, and community support for denormalisation of tobacco use needs to be strengthened. ${ }^{4}$ Additionally, the shortage of healthcare professionals in African countries ${ }^{13} 14$ may limit the availability of tobacco control and cessation interventions by trained professionals. Thus, the role of teachers may even be more important in such settings as school personnel may be one of the relatively few sources of information and advice to adolescents and youths about health concerns, including tobacco prevention.

Our results also showed that respondents from countries with mandatory health warning labels on tobacco products were less likely to be unaware of several health consequences of tobacco use. Graphic health warning labels have been associated with reduced smoking 
Table 3 Multivariate logistic regression analyses* assessing factors associated with unawareness of different health consequences of tobacco use among school personnel from 29 African countries, 2006-2011 ( $n=17$ 929)

\begin{tabular}{|c|c|c|c|c|c|c|c|}
\hline Characteristic & Category & $\begin{array}{l}\text { Unawareness that } \\
\text { tobacco use does } \\
\text { not cause malaria } \\
\text { aOR }(95 \% \mathrm{Cl})\end{array}$ & $\begin{array}{l}\text { Unawareness that } \\
\text { tobacco use is } \\
\text { addictive } \\
\text { aOR }(95 \% \mathrm{Cl})\end{array}$ & $\begin{array}{l}\text { Unawareness that } \\
\text { tobacco use } \\
\text { causes lung } \\
\text { cancer } \\
\text { aOR }(95 \% \mathrm{Cl})\end{array}$ & $\begin{array}{l}\text { Unawareness that } \\
\text { tobacco use } \\
\text { causes heart } \\
\text { disease } \\
\text { aOR }(95 \% \mathrm{Cl})\end{array}$ & $\begin{array}{l}\text { Unawareness that } \\
\text { secondhand } \\
\text { smoke exposure } \\
\text { is harmful } \\
\text { aOR }(95 \% \mathrm{Cl})\end{array}$ & $\begin{array}{l}\text { Unawareness in } \\
\text { one or more } \\
\text { domains } \\
\text { aOR }(95 \% \mathrm{Cl})\end{array}$ \\
\hline Extent & Not at all (referent) & & & & & & \\
\hline $\begin{array}{l}\text { involved in } \\
\text { teaching about }\end{array}$ & $\begin{array}{l}\text { Not primary duty, } \\
\text { teach sometimes }\end{array}$ & $0.86(0.65$ to 1.14$)$ & 0.79 (0.58 to 1.07$)$ & $0.62(0.38$ to 1.01$)$ & $0.54(0.37$ to 0.77$) \dagger$ & 0.77 (0.43 to 1.37$)$ & $0.73(0.55$ to 0.98$) \dagger$ \\
\hline health & $\begin{array}{l}\text { Primary duty, } \\
\text { teach a lot }\end{array}$ & $0.80(0.56$ to 1.15$)$ & $1.01(0.74$ to 1.38$)$ & $0.38(0.17$ to 0.83$) \dagger$ & $0.37(0.23$ to 0.58$) \dagger$ & 0.65 (0.37 to 1.13$)$ & $0.70(0.52$ to 0.96$) \dagger$ \\
\hline \multirow[t]{5}{*}{ Region } & \multicolumn{7}{|c|}{ Southern Africa (referent) } \\
\hline & West Africa & 1.76 (1.34 to 2.32$) \dagger$ & 1.31 (0.94 to 1.82$)$ & $0.84(0.37$ to 1.91$)$ & $0.21(0.13$ to 0.36$) \dagger$ & $0.22(0.10$ to 0.45$) \dagger$ & $1.16(0.87$ to 1.53$)$ \\
\hline & Central Africa & $1.36(0.98$ to 1.88$)$ & $1.64(1.08$ to 2.49$) \dagger$ & 1.65 (0.89 to 3.07$)$ & $0.49(0.29$ to 0.81$) \dagger$ & $0.35(0.18$ to 0.70$) \dagger$ & 0.95 (0.67 to 1.35$)$ \\
\hline & Eastern African & 0.75 (0.55 to 1.03$)$ & $1.63(1.19$ to 2.23$) \dagger$ & 1.29 (0.75 to 2.24$)$ & $0.50(0.35$ to 0.72$) \dagger$ & $0.67(0.40$ to 1.11$)$ & $0.78(0.54$ to 1.15$)$ \\
\hline & Northern Africa & $0.83(0.62$ to 1.11$)$ & $0.83(0.53$ to 1.29$)$ & 0.97 (0.49 to 1.92$)$ & $0.12(0.07$ to 0.21$) \dagger$ & $0.33(0.17$ to 0.64$) \dagger$ & $0.61(0.46$ to 0.81$) \dagger$ \\
\hline \multirow{4}{*}{ Age, years } & $\begin{array}{l}\text { (per unit increase) } \\
<30 \text { (referent) }\end{array}$ & $0.92(0.80$ to 1.06$)$ & $0.62(0.53$ to 0.71$) \dagger$ & $0.74(0.59$ to 0.95$) \dagger$ & $0.73(0.62$ to 0.86$) \dagger$ & $0.72(0.58$ to 0.89$) \dagger$ & 0.71 (0.58 to 0.86$) \dagger$ \\
\hline & $30-39$ & $0.84(0.65$ to 1.07$)$ & $0.78(0.55$ to 1.11$)$ & $0.46(0.26$ to 0.82$) \dagger$ & 0.85 (0.57 to 1.28$)$ & 1.30 (0.70 to 2.43$)$ & $0.90(0.67$ to 1.21$)$ \\
\hline & $40-49$ & $0.70(0.52$ to 0.94$) \dagger$ & 0.76 (0.48 to 1.20$)$ & $0.49(0.23$ to 1.02$)$ & $0.92(0.56$ to 1.51$)$ & 1.18 (0.68 to 2.03$)$ & 0.79 (0.57 to 1.09$)$ \\
\hline & $\geq 50$ & 0.85 (0.58 to 1.23$)$ & 0.65 (0.37 to 1.13$)$ & $0.37(0.15$ to 0.89$) \dagger$ & 1.15 (0.60 to 2.23$)$ & 0.64 (0.32 to 1.29$)$ & $0.82(0.56$ to 1.20$)$ \\
\hline \multirow[t]{2}{*}{ Type of staff } & Teacher (referent) & & & & & & \\
\hline & $\begin{array}{l}\text { Administrative } \\
\text { Male (referent) }\end{array}$ & 0.81 (0.60 to 1.09$)$ & 1.31 (0.90 to 1.92$)$ & 0.79 (0.40 to 1.56$)$ & 0.72 (0.43 to 1.20$)$ & $0.34(0.18$ to 0.62$) \dagger$ & 0.82 (0.62 to 1.09$)$ \\
\hline Sex & Female & 1.00 (0.76 to 1.32$)$ & 1.14 (0.92 to 1.42$)$ & $0.52(0.32$ to 0.86$) \dagger$ & $1.20(0.91$ to 1.58$)$ & $1.18(0.75$ to 1.87$)$ & $1.05(0.82$ to 1.34$)$ \\
\hline \multirow[t]{2}{*}{ Tobacco Use } & Non-smoker & & & & & & \\
\hline & $\begin{array}{l}\text { Smoker } \\
\text { No (referent) }\end{array}$ & 0.69 (0.43 to 1.09$)$ & 1.14 (0.69 to 1.87$)$ & 1.61 (0.70 to 3.73$)$ & 1.64 (0.99 to 2.72 ) & $3.07(1.79$ to 5.24$) \dagger$ & 1.01 (0.64 to 1.61$)$ \\
\hline $\begin{array}{l}\text { Presence of } \\
\text { mandatory } \\
\text { cigarette } \\
\text { health } \\
\text { warnings }\end{array}$ & $\begin{array}{l}\text { No (referent) } \\
\text { Yes }\end{array}$ & 1.25 (0.98 to 1.59$)$ & $0.37(0.30$ to 0.48$) \dagger$ & $0.54(0.31$ to 0.92$) \dagger$ & $0.30(0.20$ to 0.46$) \dagger$ & $0.50(0.26$ to 0.98$) \dagger$ & $0.51(0.37$ to 0.71$) \dagger$ \\
\hline Access to & No (referent) & & & & & & \\
\hline $\begin{array}{l}\text { tobacco } \\
\text { educational } \\
\text { materials in } \\
\text { school }\end{array}$ & Yes & 0.95 (0.76 to 1.20$)$ & 0.80 (0.60 to 1.06$)$ & 0.83 (0.48 to 1.43$)$ & 0.68 (0.43 to 1.08$)$ & $0.72(0.44$ to 1.18$)$ & 0.91 (0.73 to 1.15$)$ \\
\hline Presence of & No (referent) & & & & & & \\
\hline $\begin{array}{l}\text { tobacco retail } \\
\text { outlets on } \\
\text { campus }\end{array}$ & Yes & 1.67 (0.90 to 3.13$)$ & 1.52 (0.89 to 2.59$)$ & $2.09(1.07$ to 4.08$) \dagger$ & 1.13 (0.66 to 1.93$)$ & 1.41 (0.65 to 3.09$)$ & 1.65 (0.86 to 3.18$)$ \\
\hline
\end{tabular}


Table 4 Multivariate logistic regression analyses* assessing impact of unawareness of the health consequences of tobacco use on attitudes and behaviour towards tobacco control programmes among school personnel from 29 African countries, 2006-2011 ( $n=17$ 929)

\begin{tabular}{|c|c|c|c|}
\hline outcomes & $\begin{array}{l}\text { Primary predictor: number of } \\
\text { distinct health consequences of } \\
\text { tobacco use respondent ignorant of }\end{array}$ & $\begin{array}{l}\text { Adjusted effect of ignorance of the } \\
\text { health consequences of tobacco use } \\
\text { on outcome: aOR }(95 \% \mathrm{Cl})^{*}\end{array}$ & p Value \\
\hline \multirow[t]{4}{*}{ Current smoking } & None (referent) & & \\
\hline & One & $1.01(0.62$ to 1.64$)$ & 0.959 \\
\hline & Two & 0.94 (0.47 to 1.87$)$ & 0.867 \\
\hline & Three or more & 2.14 (1.10 to 4.17$)$ & 0.025 \\
\hline \multirow{4}{*}{$\begin{array}{l}\text { 'Not at all concerned' about } \\
\text { tobacco use among youths in } \\
\text { the community }\end{array}$} & None (referent) & & \\
\hline & One & 1.86 (1.19 to 2.92$)$ & 0.007 \\
\hline & Two & 2.54 (1.50 to 4.30$)$ & 0.001 \\
\hline & Three or more & 6.00 (2.79 to 12.91$)$ & $<0.001$ \\
\hline \multirow{4}{*}{$\begin{array}{l}\text { Perception that Teacher tobacco } \\
\text { use does not influence youth } \\
\text { tobacco use }\end{array}$} & None (referent) & & \\
\hline & One & 1.01 (0.53 to 1.92$)$ & 0.979 \\
\hline & Two & 3.88 (2.28 to 6.62$)$ & $<0.001$ \\
\hline & Three or more & $4.79(2.63$ to 8.75$)$ & $<0.001$ \\
\hline \multirow{4}{*}{$\begin{array}{l}\text { Never advised student to stop } \\
\text { using tobacco }\end{array}$} & None (referent) & & \\
\hline & One & 1.19 (0.89 to 1.58$)$ & 0.243 \\
\hline & Two & 1.54 (0.95 to 2.49$)$ & 0.081 \\
\hline & Three or more & $2.74(1.48$ to 5.08$)$ & 0.001 \\
\hline \multirow{4}{*}{$\begin{array}{l}\text { Non-support of policies } \\
\text { prohibiting tobacco use on } \\
\text { campus by students }\end{array}$} & None (referent) & & \\
\hline & One & 0.71 (0.41 to 1.21$)$ & 0.205 \\
\hline & Two & 1.85 (1.01 to 3.38$)$ & 0.046 \\
\hline & Three or more & $1.68(0.80$ to 3.54$)$ & 0.173 \\
\hline \multirow{4}{*}{$\begin{array}{l}\text { Non-support of policies } \\
\text { prohibiting tobacco use on } \\
\text { campus by school personnel }\end{array}$} & None (referent) & & \\
\hline & One & 1.79 (1.02 to 3.13$)$ & 0.042 \\
\hline & Two & 4.45 (1.95 to 10.16$)$ & $<0.001$ \\
\hline & Three or more & 4.56 (2.01 to 10.38$)$ & $<0.001$ \\
\hline \multirow{4}{*}{$\begin{array}{l}\text { Non-support of policies } \\
\text { prohibiting tobacco use in all } \\
\text { public areas }\end{array}$} & None (referent) & & \\
\hline & One & 1.64 (1.10 to 2.44$)$ & 0.015 \\
\hline & Two & 5.44 (3.12 to 9.50$)$ & $<0.001$ \\
\hline & Three or more & 5.39 (2.94 to 9.88$)$ & $<0.001$ \\
\hline \multirow{4}{*}{$\begin{array}{l}\text { Non-support of bans on tobacco } \\
\text { industry sponsorship of school or } \\
\text { extracurricular activities }\end{array}$} & None (referent) & & \\
\hline & One & 1.47 (1.07 to 2.02$)$ & 0.017 \\
\hline & Two & 1.91 (1.31 to 2.76$)$ & 0.001 \\
\hline & Three or more & 2.98 (1.81 to 4.89$)$ & $<0.001$ \\
\hline \multirow{4}{*}{$\begin{array}{l}\text { Non-support of bans on all } \\
\text { tobacco advertisements }\end{array}$} & None (referent) & & \\
\hline & One & $1.24(0.85$ to 1.81$)$ & 0.266 \\
\hline & Two & 1.78 (1.05 to 3.01$)$ & 0.031 \\
\hline & Three or more & 2.68 (1.56 to 4.62$)$ & $<0.001$ \\
\hline \multirow{4}{*}{$\begin{array}{l}\text { Non-support of price increase on } \\
\text { tobacco products }\end{array}$} & None (referent) & & \\
\hline & One & $0.96(0.72$ to 1.29$)$ & 0.798 \\
\hline & Two & $1.12(0.76$ to 1.64$)$ & 0.577 \\
\hline & Three or more & 1.67 (1.01 to 2.76$)$ & 0.044 \\
\hline
\end{tabular}

cravings and intentions, reductions in overall smoking prevalence. ${ }^{15-18}$ However, Mauritius is the only African country to have implemented pictorial warnings. ${ }^{19}$ Other population-based strategies to warn about the dangers of tobacco use include the use of hard-hitting mass media campaigns, which have also been shown to increase quit attempts and prevent tobacco use among youths. ${ }^{15} 162021$ Despite the proven effectiveness of hardhitting mass media campaigns, only 10 countries in the
WHO African region reported having had at least one national anti-tobacco mass media campaign during 2009-2010. ${ }^{1}$

Other public health campaigns for infectious diseases have, however, been widely implemented in the African region with some success in promoting health-seeking behaviour. For example, mass media campaigns on malaria prevention have been associated with increased use of insecticide-treated bed nets among children and 
pregnant women in Nigeria and Ghana, while HIV/ AIDS campaigns have increased condom use and HIV testing among South African youths. ${ }^{22-25}$

Enhanced and sustained efforts to develop antitobacco mass media educational campaigns by national governments in Africa as part of a comprehensive tobacco control programme may help to prevent tobacco use by never users, help current tobacco users to stop and prevent relapse among former tobacco users.

This study's strength is the use of large, relatively recent, representative datasets from 29 African countries. The use of standardised methodology across all participating sites ensures comparability of estimates across countries. In addition, we assessed several domains of knowledge about the health consequences of tobacco use. Nonetheless, the findings in this study have some limitations. First, the self-reported nature of all measures in the study may result in some misreporting. Second, the cross-sectional design precludes causal inferences, and only associations can be drawn. Finally, since nationally representative data were not available for all countries within each United Nations region, these findings may not be representative of the respective United Nations regions.

\section{CONCLUSION}

This study showed that, on average, two-thirds of school personnel in all countries surveyed were unaware of at least one health consequence of tobacco use. School personnel who were involved in teaching about health, and those in countries with mandatory health warnings on tobacco products were less likely to be unaware of the health consequences of tobacco use. Unawareness of the health consequences of tobacco use was associated with being a current tobacco user, having little involvement in, or concern about, tobacco prevention activities among youths and showing poor support for tobacco control policies. These findings underline the need to intensify efforts to warn about the dangers of tobacco use using proven population-based strategies.

\section{Author affiliations \\ ${ }^{1}$ Africa Tobacco Control Regional Initiative, Ogba-Ikeja, Lagos, Nigeria \\ ${ }^{2}$ School of Public Health, Imperial College London, London, UK}

Contributors ITA conceptualised and designed the study, carried out the initial analyses and drafted the initial manuscript. FTF critically reviewed and revised the manuscript. Both authors approved the final manuscript.

Funding This research received no specific grant from any funding agency in the public, commercial or not-for-profit sectors.

Competing interests None.

Provenance and peer review Not commissioned; externally peer reviewed.

Data sharing statement No additional data are available.

Open Access This is an Open Access article distributed in accordance with the Creative Commons Attribution Non Commercial (CC BY-NC 4.0) license, which permits others to distribute, remix, adapt, build upon this work noncommercially, and license their derivative works on different terms, provided the original work is properly cited and the use is non-commercial. See: http:// creativecommons.org/licenses/by-nc/4.0/

\section{REFERENCES}

1. World Health Organization. WHO Report on the Global Tobacco Epidemic 2013, 2013. Enforcing bans on tobacco advertising promotion and sponsorship. http://apps.who.int/202A1F3B-6F1E4162-96E2-979BCB3B5F15/FinalDownload/ Downloadld-BD5DACF211A245F200FD6C52B616EE29/ 202A1F3B-6F1E-4162-96E2-979BCB3B5F15/iris/bitstream/10665/ 85380/1/9789241505871_eng.pdf (accessed 10 Dec 2013).

2. United Nations Department of Economic and Social Affairs. Population Division, Population Estimates and Projections Section. Secondary Population Division, Population Estimates and Projections Section. http://esa.un.org/unpd/wpp/unpp/p2k0data.asp (assessed 6 Jul 2014).

3. The World Bank. Population Estimates and Projections. Secondary Population Estimates and Projections. http://datatopics.worldbank. org/hnp/popestimates (accessed 23 Jun 2014).

4. Tumwine J. Implementation of the framework convention on tobacco control in Africa: current status of legislation. Int J Environ Res Public Health 2011;8:4312-31.

5. World Health Organization. Global status report on noncommunicable diseases 2010. Geneva: World Health Organization, 2011. http://whqlibdoc.who.int/publications/2011/ 9789240686458_eng.pdf?ua $=1$ (Accessed 6 July 2014).

6. World Health Organization. WHO Framework Convention on Tobacco Control. Geneva: World Health Organization, 2003. http:// whqlibdoc.who.int/publications/2003/9241591013.pdf (accessed 23 Sep 2012).

7. World Health Organization. WHO Report on the Global Tobacco Epidemic 2011. Warning about the dangers of tobacco, 2011. http:// whqlibdoc.who.int/publications/2011/9789240687813_eng.pdf?ua=1 (Accessed 6 Jul 2014).

8. World Health Organization. Global Tobacco Surveillance System Data. http://apps.nccd.cdc.gov/gtssdata/Ancillary/DataReports.aspx? CAID $=1$ (accessed 5 Jul 2014)

9. United Nations Statistics Division. Composition of macro geographical (continental) regions, geographical sub-regions, and selected economic and other groupings. Secondary Composition of macro geographical (continental) regions, geographical sub-regions, and selected economic and other groupings. http://unstats.un.org/unsd/ methods/m49/m49regin.htm (accessed 6 Jul 2014).

10. Siahpush M, McNeill A, Hammond D, et al. Socioeconomic and country variations in knowledge of health risks of tobacco smoking and toxic constituents of smoke: results from the 2002 International Tobacco Control (ITC) Four Country Survey. Tob Control 2006;15 (Suppl 3):iii65-70.

11. Reddy P, Meyer-Weitz A, Yach D. Smoking status, knowledge of health effects and attitudes toward tobacco control in South Africa. S Afr Med J 1996:86:1389-93.

12. US Department of Health and Human Services. The health consequences of involuntary exposure to tobacco smoke: a report of the Surgeon General. Atlanta, GA: U.S Department of Health and Human Services, Centers for Disease Control and Prevention, National Center for Chronic Disease Prevention and Health Promotion, Office on Smoking and Health, 2006.

13. Naicker S, Plange-Rhule J, Tutt RC, et al. Shortage of healthcare workers in developing countries-Africa. Ethn Dis 2009;19(1 Suppl 1): S1-60-4.

14. Kinfu $\mathrm{Y}$, Dal Poz MR, Mercer $\mathrm{H}$, et al. The health worker shortage in Africa: are enough physicians and nurses being trained? Bull World Health Organ 2009;87:225-30.

15. Hammond D, Fong GT, McDonald PW, et al. Graphic Canadian cigarette warning labels and adverse outcomes: evidence from Canadian smokers. Am J Public Health 2004;94:1442-5.

16. Huang J, Chaloupka FJ, Fong GT. Cigarette graphic warning labels and smoking prevalence in Canada: a critical examination and reformulation of the FDA regulatory impact analysis. Tob Control 2014;23(Suppl 1):i7-12.

17. Wang AL, Romer D, Elman I, et al. Emotional graphic cigarette warning labels reduce the electrophysiological brain response to smoking cues. Addict Biol 2013. doi:10.1111/adb.12117

18. Villanti AC, Cantrell J, Pearson JL, et al. Perceptions and perceived impact of graphic cigarette health warning labels on smoking behavior among U.S. young adults. Nicotine Tob Res 2014;16:469-77. 
19. Framework Convention Alliance. Secondary. http://www.fctc.org/ fca-news/packaging-and-labelling/251-mauritius-leads-africa-withcigarette-pack-warnings (accessed 5 Jun 2014)

20. Centers for Disease C, Prevention. Increases in quitline calls and smoking cessation website visitors during a national tobacco education campaign-March 19-June 10, 2012. MMWR Morb Mortal Wkly Rep 2012;61:667-70.

21. Farrelly MC, Niederdeppe J, Yarsevich J. Youth tobacco prevention mass media campaigns: past, present, and future directions. Tob Control 2003;12(Suppl 1):i35-47.

22. Ankomah A, Adebayo SB, Arogundade ED, et al. The effect of mass media campaign on the use of insecticide-treated bed nets among pregnant women in Nigeria. Malar Res Treat 2014;2014:694863.

23. Owusu Adjah ES, Panayiotou AG. Impact of malaria related messages on insecticide-treated net (ITN) use for malaria prevention in Ghana. Malar J 2014;13:123.

24. Peltzer K, Parker W, Mabaso M, et al. Impact of national HIV and AIDS communication campaigns in South Africa to reduce HIV risk behaviour. Sci World J 2012;2012:384608.

25. Bertrand JT, Anhang R. The effectiveness of mass media in changing HIV/AIDS-related behaviour among young people in developing countries. World Health Organ Tech Rep Ser 2006;938:205-41. 